\title{
Coral expansion in Sydney and associated coral-reef fishes
}

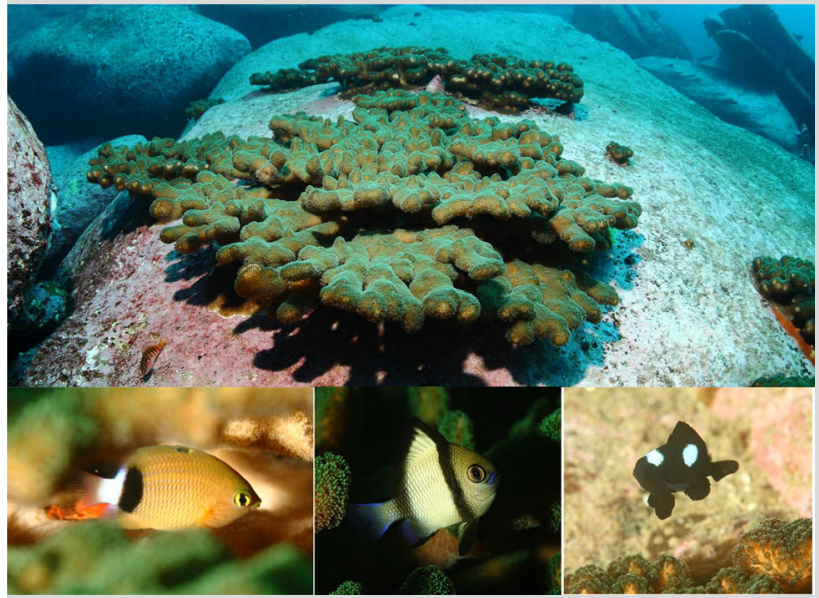

Fig. 1 a Pocillopora aliciae coral colonies off Sydney; supported species (lower panels, left to right): b Plectroglyphidodon dickii, c Dascyllus reticulatus, d Dascyllus trimaculatus (photographs: John Sear)
Climate change is driving marine tropical species poleward, but successful range shifts require a suitable larval transport environment, warm water, and habitat in the temperate receiving environment. In South-East Australia, poleward advection of coral-reef fish species has been well documented (e.g., Booth et al. 2018); however, a key habitat for coral-reef fish is coral itself, which has generally not spread as far poleward as fishes and other invertebrates (Baird et al. 2012).

Here we describe observations of new tropical corals appearing in exposed Sydney reef areas, and the coral-reef species that this benefits. Sydney is well south of the nearest coral reefs $\left(33.8^{\circ} \mathrm{S}, 151.3^{\circ} \mathrm{N}\right)$ and supports 3 species of temperate encrusting coral, but previously no branching corals. The coral observed (Fig. 1a) is Pocillopora aliciae (Pocilloporidae) (Schmidt-Roach et al. 2013; A. Baird pers. comm., https://www.inaturalist.org/observations/6138055), previously recorded at Port Stephens, $120 \mathrm{~km}$ north. JS has observed the establishment of this coral "bed" since 2013.

The initial discovery was of a number of relatively small individual coral heads, each less than $20 \mathrm{~cm}$ across. Subsequent visits observed significant growth of the corals, and proliferation of new corals along the bare ocean-facing rock platforms that are exposed to wave action (Fig. 1a). Larger growths now exceed $30 \mathrm{~cm}$ across. The largest patch is at $10 \mathrm{~m}$ depth on a rock substrate; however, smaller colonies have been found in more protected areas of adjacent Cabbage Tree Bay. As far as we are aware, this is the furthest south of any tropical coral recorded.

Associated with the new coral bed are several tropical species previously unrecorded in long-term monitoring described above, including Plectroglyphidodon dickii (Pomacentridae: Fig. 1b), Dascyllus reticulatus (Pomacentridae: Fig. 1c), Paragobiodon modestus (Gobiidae) as well as species rarely recorded in Sydney such as D. trimaculatus (Fig. 1d). The expansion of the coral beds documented here is likely to continue, given sea temperature and East Australian Current strengthening predictions (e.g., Booth et al. 2018) and we expect in future to record more new associated tropical species facilitated by the corals.

Acknowledgements The authors thank Prof. Andrew Baird for advice on coral identification.

\section{References}

Baird AH, Sommer B, Madin JS (2012) Pole-ward range expansion of Acropora spp. along the east coast of Australia. Coral Reefs 31:1063

Booth DJ, Beretta GA, Brown L, Figueira WF (2018) Predicting success of range-expanding coral reef fish in temperate habitats using temperatureabundance relationships. Front Mar Sci 5:31. https://doi.org/10.3389/fmars.2018.00031

Schmidt-Roach S, Miller KJ, Andreakis N (2013) Pocillopora aliciae: a new species of scleractinian coral (Scleractinia: Pocilloporidae) from subtropical eastern Australia. Zootaxa 4:576-582

D. J. Booth (iD $(\bowtie)$

Fish Ecology Lab, University of Technology, Sydney, Sydney, NSW 2007, Australia

e-mail: David.Booth@uts.edu.au

J. Sear

Eco Divers, Sydney, Australia

e-mail: johnsear@hotmail.com 